\title{
KIPRAH TENAGA PENDIDIK EKONOMI / AKUNTANSI DALAM MENGAPLIKASIKAN KOMPETENSI DI KELUARGA, MASYARAKAT, ORGANISASI DAN DUNIA KERJA
}

\author{
Diana Widhi Rachmawati ${ }^{1}$, Hendri Gunawan ${ }^{2}$, M. Toyib ${ }^{3}$, Riswan Aradea ${ }^{4}$ dan Januardi $^{5}$ \\ Program Studi Pendidikan Akuntansi Universitas PGRI Palembang \\ Email : dianawidhi72@yahoo.com ${ }^{1}$, jayasampurna85@gmail.com ${ }^{2}$, \\ muhammad_toyib83@yahoo.com ${ }^{3}$,riswanaradea@gmail.com ${ }^{4}$,januardibk1@gmail.com ${ }^{5}$
}

\begin{abstract}
Abstrak
Dosen Program Studi Pendidikan Akuntansi FKIP Universitas PGRI Palembang berkeinginan untuk melakukan pelaksanaan Pengabdian kepada Masyarakat (PkM) tentang "Kiprah Tenaga Pendidik Ekonomi Akuntansi dalam Mengaplikasikan Kompetensi di Keluarga, Masyarakat, Organisasi, dan Dunia Kerja. Tujuan Pengabdian ini adalah pelatihan kepada alumni program studi pendidikan akumtansi Fakultas Keguruan dan Ilmu Pendidikan Universitas PGRI Palembang dalam Rangka Mengembangkan Skill tenaga pendidik ekonomi/akuntansi dalam mengaplikasan kompetensi di keluarga, masyarakat, organisasi dan dunia keluarga yang sekaligus juga merupakan objek dan sasarannya. Kegiatan ini dilakukan selama satu hari dengan narasumber berasal dari lima orang dosen Pendidikan Akuntansi Universitas PGRI Palembang. Metode yang digunakan adalah pelatihan para alumni Prodi Pendidikan Akuntansi dalam mengaplikasan kompetensi di keluarga, masyarakat, organisasi dan dunia keluarga. Kegiatan diawali dengan penyampaian materi oleh dosen pemateri dan memberikan kesempatan kepada 40 orang alumni yang hadir untuk memberikan pendapat atau mengajukan beberapa pertanyaan. Kegiatan pelatihan ini akan dilaksanakan selama satu hari pada hari Sabtu tanggal 19 bulan Desember 2015. Bertempat di Gedung Science Centre atau Lab Terpadu Universitas PGRI Palembang.
\end{abstract}

\section{Kata Kunci: Kiprah Tenaga Pendidik di Masyarakat}

\begin{abstract}
Lecturers from the Accounting Education Study Program of the FKIP University of Palembang PGRI wish to implement in the form of Community Service about the Progress of Economic/Accounting Educators in Applying Competencies in Families, Communities, Organizations and the World of Work.The purpose of this service is to train alumni of the accreditation education study program at the Teaching and Education Faculty of Palembang PGRI University in order to develop skills in teaching economics/accounting staff in applying the competencies in family, community, organization and family world which are also objects and targets.. This activity was carried out for one day with speakers from five lecturers of Accounting Education at PGRI Palembang University. The method used is training of study program Alumni Accumulation Education in applying the competencies in family, community, organization and family world. The activity begins with the delivery of material by the lecturer and gives the opportunity for 40 alumni who are present to give opinions or ask questions.This training activity will be held for one day on Saturday the 19th of December 2015. Located at the Science Center Building or Integrated Lab of Palembang PGRI University.
\end{abstract}

Keywords: The Gait of Educators in the Community 


\section{Pendahuluan}

Perkembangan ekonomi sangat berkembang pesat dewasa ini menyebabkan banyak tuntutan yang harus dipenuhi dalam pencapaian pemenuhannya. Hal inilah yang melahirkan banyak inovasi untuk tetap bertahan hidup dalam memenuhi kebutuhan hidup.

Banyaknya pencari kerja dewasa ini yang kurang begitu diimbangi dengan peluang kerja yang menuntut setiap individu harus memiliki nilai lebih untuk mampu bersaing di dunia kerja.

Penempatan kerja saat ini banyak terbuka di segala bidang, namun disayangkan masih banyak juga terdapat keterbatasan yang dimiliki oleh individu untuk dapat masuk ke bidang-bidang yang dibutuhkan karena belum memiliki kompetensi seperti yang diharapkan oleh para oemberi kerja.

Untuk dapat tetap memiliki inovasi sehingga dapat berdaya saing tinggi, maka setiap individu para pencari kerja harus memiliki kemampuan seperti yang diharapkan, oleh sebab itulah peran guru sangat diharapkan dikarenakan bukan hanya sebagai tenaga pendidik, guru harus dapat menyiapkan anak-anak didiknya untuk mempunyai kompetensi yang handal sehingga saat anak-anaknya turun ke dunia kerja mereka sudah memiliki kemampuan di bidang-bidang tertentu sehingga dapat bersaing di dunia usaha.

Purwanto (1997) Guru merupakan orang yang diserahi tanggung jawab sebagai pendidik di lingkungan sekolah.

Bastian (2008) Akuntansi Pendidikan diharapkan dapat memberikan arti penting dalam menjamin akuntabilitas penyelenggaraan pendidikan dari lembaga atau organisasi pendidikan sebagaimana tercakup dalam Undang-Undang Pendidikan Nasional.

Abdullah, NS., dkk., (2018), Ekonomi Pendidikan bertujuan untuk memberikan dasar-dasar pemikiran tentang nilai ekonomi dari pendidikan baik untuk kepentingan individual maupun lembaga atau bangsa (negara)

Dangfeby (2016) Dunia Kerja membutuhkan persiapan secara khusus dari persiapan kerja sampai ke kammpuan bertahan dan berkembang sehingga dapat mewujudkan pencapaian yang diharapkan di dunia kerja.

Berdasarkan latar belakang di atas, maka para dosen dari Program Studi Pendidikan Akuntansi FKIP Universitas PGRI Palembang berkeinginan untuk melakukan pelaksanaan Tridarma Perguruan Tinggi berupa Pengabdian kepada Masyarakat $(\mathrm{PkM})$ tentang "Kiprah Tenaga Pendidik Ekonomi Akuntansi dalam Mengaplikasikan Kompetensi di Keluarga, Masyarakat, Organisasi, dan Dunia Kerja.

Adapun tujuan diadakannya kegiatan pengabdian pada masyarakat ini adalah:

a. Melaksanakan Tri Dharma Perguruan Tinggi

b. Merealisasikan program kerja Program Studi Pendidikan Akuntansi, Jurusan Pendidikan IPS pada FKIP Universitas PGRI Palembang.

c. Meningkatkan pemahaman alumni program studi pendidikan akuntansi Fakultas Keguruan dan Ilmu Pendidikan Universitas PGRI Palembang menuju kiprah tenaga pendidik ekonomi/ akuntansi dalam mengaplikasikan kompetensi di keluarga, masyarakat, organisasi dan dunia keluarga.

Manfaat dari kegiatan ini dapat dilihat dari, pertama, pencapaian target, yaitu bagi peserta dapat mengetahui pentingnya alumni 
program studi Pendidikan Akuntansi Fakultas Keguruan dan Ilmu Pendidikan Universitas PGRI Palembang menuju kiprah tenaga pendidik ekonomi/akuntansi dalam mengaplikasan kompetensi di keluarga, masyarakat, organisasi dan dunia keluarga.

Kedua, Luaran, yaitu hasil pengabdian hendaknya dapat menjadi suplemen pengayaan bahan ajar. Selain itu juga dapat menjadi arsip bagi Universitas PGRI Palembang.

\section{Bahan dan Metode Pelaksanaan}

Dasar kegiatan pengabdian kepada masyarakat ini adalah:

a. Undang-Undang Nomor 20 Tahun 2003 tentangSistem Pendidikan Nasional

b. Undang-Undang Nomor 14 Tahun 2005 tentang Guru dan Dosen

c. Peraturan Pemerintah Nomor 60 Tahun 1999 tentang Pendidikan Tinggi

d. Peraturan Pemerintah Nomor 19 Tahun 2005 tentang Standar Nasional Pendidikan

e. Peraturan Pemerintah Nomor 74 Tahun 2008 tentang Guru

f. Pedoman Akademik FKIP Universitas PGRI Palembang.

g. Program Kerja Prodi Pendidikan Akuntansi FKIP Universitas PGRI Palembang.

Akuntansi dalam Mengaplikasikan Kompetensi di Keluarga, Masyarakat, Organisasi, dan Dunia Kerja”.

Narasumber, Peserta, Pendukung

\section{Pelaksana}

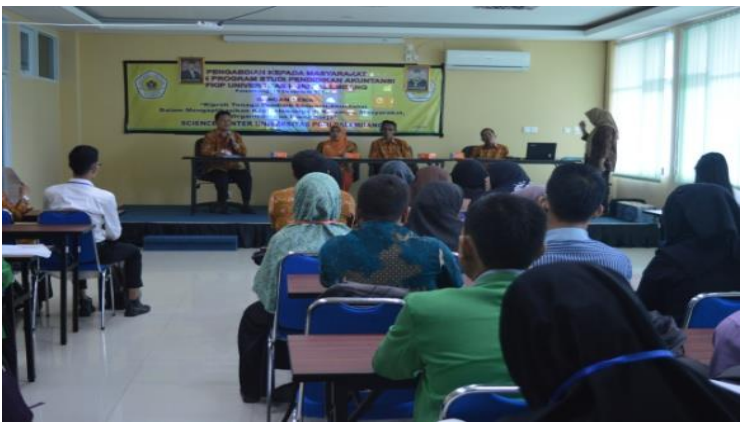

Narasumber pada kegiatan ini adalah dosen pada Program Studi Pendidikan Akuntansi FKIP Universitas PGRI Palembang yang berjumlah 5 orang.

\section{Waktu dan Tempat Pelaksanaan}

Kegiatan pelatihan ini akan dilaksanakan selama satu hari pada hari Sabtu tanggal 19 bulan Desember 2015. Bertempat di ruang 406 Gedung Science Centre Universitas PGRI Palembang.

\section{Dana Pelaksanaan}

Dana pelaksanaan pada kegiatan ini bersumber dari dana Universitas PGRI Palembang.

\section{Hasil dan Pembahasan}

Kegiatan pengabdian kepada masyarakat yang dilakukan oleh lima dosen program studi Pendidikan Akuntansi di Fakultas Keguruan dan Ilmu Pendidikan Universitas PGRI Palembang ini telah terlaksana dengan baik dan selesai sebagaimana waktu yang telah ditentukan

Rangkaian acara kegiatan ini dimulai dari salah satu dosen melakukan pembukaan dan pengantar serta arahan maksud dari tujuan adanya kegiatan pengabdian masyarakat yang dilakukan di Universitas PGRI Palembang. Selanjutnya dosen secara bergiliran memberikan materi sesuai dengan temanya masing-masing.

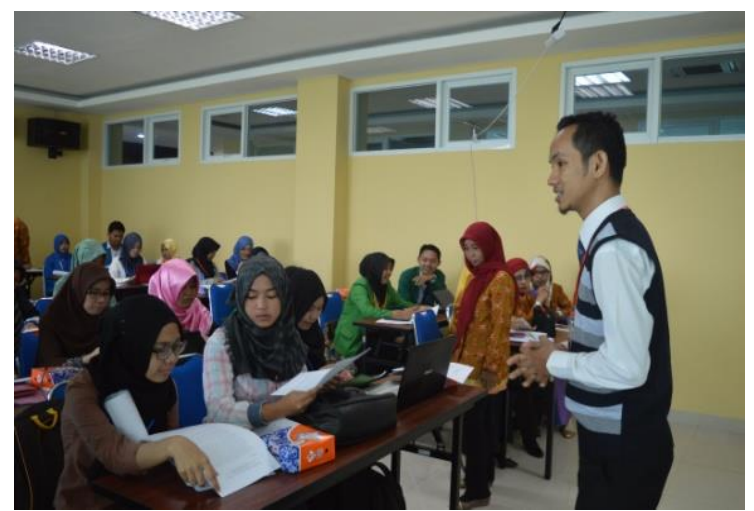


Materi pertama diawali dengan penjelasan tentang apa itu Upaya Meningkatkan Kompetensi dan Profesionalisme Guru, materi kedua dilanjutkan dengan tidak Ada Kata Terlambat untuk Berwirausaha, Materi ketiga menjelaskan tentang Meningkatkan Kemampuan dalam Malakukan Identifikasi Keaslian Mata Uang Kertas Demi Meminimalisas Kerugian pada Dunia Usaha, Materi keempat menjelaskan tentang Implementasi Pendidikan Kewirausahaan di Sekolah, dan materi kelima menjelaskan tentang Memaksimalkan Penggunaan Media Pembelajaran Akuntansi Sebagai Upaya Peningkatan Profesional Guru dalam Mengajar.

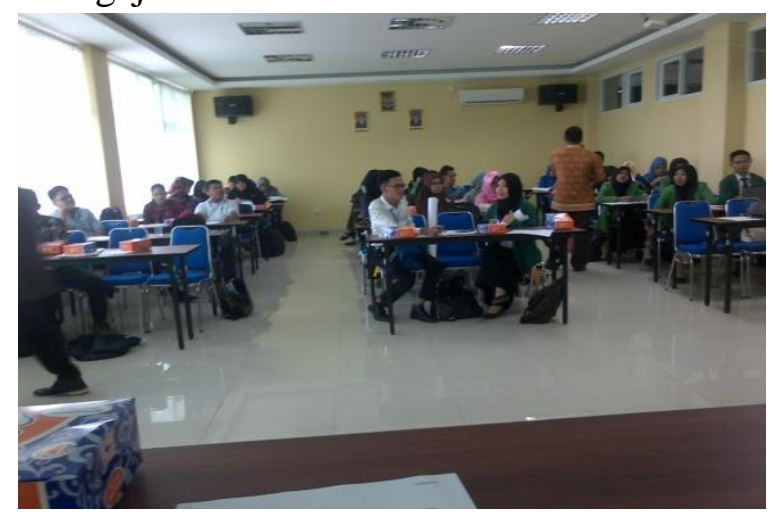

Setelah masing-masing dosen memberikan penjelasan, diberikan kesempatan untuk guru dan siswa mengajukan beberapa pertanyaan berkenaan dengan koperasi sekolah, cukup besar animo atau tanggapan dari beberapa tanggapan yang disampaikan.

\section{Penutup}

Laporan pengabdian kepada masyarakat ini dilaksanakan dan diselesaikan melalui prosedur dengan sebenar-benarnya yang diharapkan dapat memberikan kontribusi dalam pengembangan ilmu pengetahuan di kalangan para alumni dan guru. Tidak hanya itu juga, kegiatan pengabdian kepada masyarakat yang dilaksanakan pada tanggal
19 Desember 2015 dengan tema "Kiprah Tenaga Pendidik Ekonomi/Akuntansi dalam Mengaplikasikan Kompetensi di Keluarga, Masyarakat, Organisasi dan Dunia Kerja "ini juga dapat meningkatkan dan membangkitkan rasa profesionalisme dosen di lingkungan program studi Pendidikan Akuntansi Fakultas Keguruan dan Ilmu Pendidikan Universitas PGRI Palembang.

Harapannya kegiatan ini dapat terus dilaksanakan secara berkelanjutan guna memberikan pengetahuan dan memperdalam pengetahuan atau pemahaman Kiprah Tenaga Pendidik Ekonomi/Akuntansi dalam Mengaplikasikan Kompetensi di Keluarga, Masyarakat, Organisasi dan Dunia Kerja

\section{Daftar Pustaka}

Abdullah, NS., dkk. (2018). Ekonomi Pendidikan. Jakarta: Universitas Terbuka.

Bastian, Indra, (2008). Akuntansi Pendidikan. Jakarta: Erlangga

Dangfeby. (2016). A-Z Dunia Kerja. Yogya: Harfeey.

Purwanto. (1997). Pengertian Guru dan Tugas Guru, https://www.silabus.web.id. 